\title{
The End of International Adoption? \\ 必
}




\title{
Families in Focus
}

Series Editors

\author{
Naomi R. Gerstel, University of Massachusetts, Amherst \\ Karen V. Hansen, Brandeis University \\ Rosanna Hertz, Wellesley College \\ Nazli Kibria, Boston University \\ Margaret K. Nelson, Middlebury College
}

Katie L. Acosta, Amigas y Amantes: Sexually Nonconforming Latinas Negotiate Family

Riché J. Daniel Barnes, Raising the Race: Black Career Women Redefine Marriage, Motherhood, and Community

Ann V. Bell, Misconception: Social Class and Infertility in America

Amy Brainer, Queer Kinship and Family Change in Taiwan

Mignon Duffy, Amy Armenia, and Clare L. Stacey, eds., Caring on the Clock: The Complexities and Contradictions of Paid Care Work

Estye Fenton, The End of International Adoption? An Unraveling Reproductive Mar-

ket and the Politics of Healthy Babies

Anita Ilta Garey and Karen V. Hansen, eds., At the Heart of Work and Family:

Engaging the Ideas of Arlie Hochschild

Heather Jacobson, Labor of Love: Gestational Surrogacy and the Work of Making Babies

Katrina Kimport, Queering Marriage: Challenging Family Formation in the United States

Mary Ann Mason, Nicholas H. Wolfinger, and Marc Goulden, Do Babies Matter? Gender and Family in the Ivory Tower

Jamie L. Mullaney and Janet Hinson Shope, Paid to Party: Working Time and Emotion in Direct Home Sales

Markella B. Rutherford, Adult Supervision Required: Private Freedom and Public Constraints for Parents and Children

Barbara Wells, Daughters and Granddaughters of Farmworkers: Emerging from the

Long Shadow of Farm Labor 


\section{The End of \\ International Adoption?}

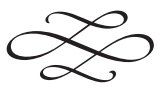

An Unraveling Reproductive Market and

the Politics of Healthy Babies

ESTYE FENTON

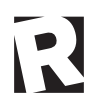

RUTGERS UNIVERSITY PRESS

NEW BRUNSWICK, CAMDEN, AND NEWARK,

NEW JERSEY, AND LONDON 
Library of Congress Cataloging-in-Publication Data

Names: Fenton, Estye, author.

Title: The end of international adoption? : an unraveling reproductive market and the politics of healthy babies / Estye Fenton.

Description: New Brunswick : Rutgers University Press, [2019] | Includes bibliographical references and index.

Identifiers: LCCN 2018032221 | ISBN 9780813599687 (pbk.) | 9780813599694

(hardcover)

Subjects: LCSH: Intercountry adoption-United States.

Classification: LCC HV875.55 .F4625 2019 | DDC 362.734—dc23

LC record available at https://lccn.loc.gov/2018032221

A British Cataloging-in-Publication record for this book is available from the British Library.

Copyright (C) 2019 by Estye Fenton

All rights reserved

No part of this book may be reproduced or utilized in any form or by any means, electronic or mechanical, or by any information storage and retrieval system, without written permission from the publisher. Please contact Rutgers University Press, 106

Somerset Street, New Brunswick, NJ 08901. The only exception to this prohibition is "fair use" as defined by U.S. copyright law.

$\infty$ The paper used in this publication meets the requirements of the American National Standard for Information Sciences-Permanence of Paper for Printed Library Materials, ANSI Z39.48-1992.

www.rutgersuniversitypress.org

Manufactured in the United States of America 